Published in final edited form as:

Pediatr Diabetes. 2018 May ; 19(3): 346-353. doi:10.1111/pedi.12597.

\title{
Genetics of type 1 diabetes
}

\author{
Maria J. Redondo ${ }^{1}$, Andrea K. Steck ${ }^{2}$, and Alberto Pugliese ${ }^{3}$ \\ ${ }^{1}$ Texas Children's Hospital, Baylor College of Medicine, Houston, TX 77030 \\ ${ }^{2}$ University of Colorado School of Medicine, Barbara Davis Center for Childhood Diabetes, \\ Aurora, CO, 80045 \\ ${ }^{3}$ Diabetes Research Institute, Department of Medicine, Division of Endocrinology and \\ Metabolism, Department of Microbiology and Immunology, Leonard Miller School of Medicine, \\ University of Miami, Miami, FL 33136
}

\section{Abstract}

Type 1 diabetes (T1D) results from immune-mediated loss of pancreatic beta cells leading to insulin deficiency. It is the most common form of diabetes in children, and its incidence is on the rise. This article reviews the current knowledge on the genetics of T1D. In particular, we discuss the influence of HLA and non-HLA genes on T1D risk and disease progression through the preclinical stages of the disease, and the development of genetic scores that can be applied to disease prediction. Racial/ethnic differences, challenges and future directions in the genetics of T1D are also discussed.

\section{Keywords}

Type 1 diabetes; genetics; HLA; etiology; epidemiology

\section{Introduction}

Type 1 diabetes (T1D) is the most common form of diabetes in children, as it accounts for approximately $80 \%$ of pediatric diabetes cases in the United States.(1) The incidence of T1D is on the rise in the United States and worldwide. (2-4) The SEARCH for Diabetes in Youth study, a population-based study designed to evaluate diabetes in youth in the United States, estimated 21.7 new cases of T1D per year per 100,000 population between 2002 and 2012, (2) and a prevalence of 1.93 cases for every 1,000 children.(5) T1D is most common among non-Hispanic whites (NHW), especially among those of Northern European descent, but it is diagnosed in all races and ethnicities. In fact, a recent report indicated that the rise in T1D incidence in the United States is most pronounced among Hispanics.(2) In contrast, T2D is more common among Hispanic, African-American, American Pacific Islander or American Indian populations than in NHW individuals.(1) There is much variation in T1D incidence in different parts of the world; for example, the incidence of T1D (per $10^{5}$ children per year) ranges from 0.1 in China and Venezuela to 36.8 in Sardinia and 36.5 in Finland.(6, 7) T1D is

Corresponding author: MJ Redondo, MD, Diabetes and Endocrinology Section, Texas Children's Hospital, Baylor College of Medicine, 6701 Fannin St. CC1020, Houston, TX 77030, redondo@ bcm.edu, Phone: 832-822-1019, Fax: 832-825-1049. 
also diagnosed in adult age, with approximately $30 \%$ of patients developing symptoms after 18 years of age. Although T1D represents $10 \%$ of adult diabetes cases overall, the absolute number of individuals diagnosed with T1D is likely higher among adults than children given the high incidence of diabetes in adults. $(8,9)$

The hallmark of T1D is beta-cell loss that leads to insulin deficiency.(10) About $90 \%$ of patients develop T1D as the result of the autoimmune destruction of beta-cells (type 1A), as marked by the presence of circulating autoantibodies to islet cell autoantigens.

Autoantibody-negative patients are classified as having "idiopathic T1D", or type 1B, which may include patients with autoimmune diabetes lacking measurable autoantibody responses to common autoantigens (11) as well as patients with rare forms of monogenic diabetes (12, 13), in addition to autoantibody false negatives. Autoantibody-negative T1D may be more common in some non-White racial groups.(14)

\section{Genetics of type 1 diabetes}

\section{Evidence for the contribution of genetics to type 1 diabetes}

The overall risk of T1D in the general population is $0.4 \%$, but it is higher in relatives of patients. For example, siblings of patients have on average a 6-7\% lifetime risk; the risk of T1D is $1.3-4 \%$ in children of a female patient and 6-9\% in children of a male patient.(15, 16) While the risk of T1D in non-identical twins is similar to that of siblings, it exceeds $70 \%$ in identical twins with long-term follow-up.(17-19) Additional evidence for the contribution of genetic factors to the etiology of T1D is the occurrence of autoimmune diabetes in association with genetic mutations affecting key genes with immune function.(20) For example, the autoimmune polyglandular syndrome type 1 (APS1) is caused by mutations in the autoimmune regulator ( $A I R E$ ) gene, which is critical for the establishment of immunological self-tolerance. $(21,22)$ Patients with APS1 have T1D, hypoparathyroidism, Addison's disease, mucocutaneous candidiasis, hepatitis, hypothyroidism, oophoritis and lymphocytic hypophysitis. Mutations in the FoxP3 gene cause an X-linked syndrome that associates immune dysregulation, polyendocrinopathy and enteropathy (IPEX syndrome). Foxp3 is a transcription factor that is essential for the development and function of regulatory $\mathrm{T}$ cells, which play a critical role in maintaining self-tolerance. $(23,24)$ Mutations in the STAT3 gene were associated with the STAT3 polyautoimmunopathy, a syndrome that includes permanent autoimmune neonatal diabetes, thyroid disease, celiac disease and intrauterine growth retardation.(25) An aberrant, activating mutation in STAT3 has recently been reported to lead to inhibition of the transcription factor Isl-1 and in turn decreased insulin expression and synthesis. (26) Although autoimmune diabetes occurring in these settings is generally thought to be different from the more frequent polygenic type, these syndromes highlight how selected genes can critically impact the development of autoimmunity.

Two major approaches have been used to study the genetics of T1D, namely candidate gene association studies and genome-wide linkage analysis studies (GWAS) (reviewed in (27)). Both approaches, although not devoid of challenges (reviewed in (28)), have resulted in an abundance of knowledge about genes and loci that confer risk and protection for T1D. 


\section{HLA region}

The HLA region on chromosome 6p21 accounts for approximately 50\% of the familial aggregation of T1D and its association with T1D has been known for over 40 years.(29)

The strongest association is with HLA DR and DQ. HLA DR and DQ are cell surface receptors that present antigens to T-lymphocytes. Both DR and DQ are alpha-beta heterodimers. The DR alpha chain is encoded by the DRA locus, and the DR beta chain is encoded by DRB loci. Similarly, DQA1 and DQB1 loci encode the alpha and beta chains, respectively, of the DQ molecule. The DR and DQ loci are highly linked to each other and, to a lesser degree, to other HLA loci.

The highest risk haplotypes are those with HLA Class II DR4-DQA1*03:01-DQB1*03:02 (also termed "DR4-DQ8" haplotype), especially the haplotypes carrying the DRB1 alleles $* 04: 05, * 04: 01$ and *04:02.(30) For example, DRB1*04:05 has an OR of 11 and DRB1*04:01 an OR of 8. The second high-risk haplotype is DRB1*03:01-DQA1*05:01DQB1*02:01 ("DR3-DRQ2" haplotype), which is highly conserved (i.e. in strong linkage disequilibrium) and has an OR of 3.6. It was recently shown that DR3 homozygotes carriers of the HLA-DRB $3 * 02: 02$ allele were at significantly higher risk of developing T1D than the individuals who were homozygous for the HLA-DRB $3 * 01: 01$.(31) Up to $90 \%$ of people with T1D carry DR4-DQ8 or DR3-DQ2 and about 30\% of patients carry both compared to $2 \%$ of the general population. The combination of those two haplotypes into the DR4-DQ8/ DR3-DQ2 genotype confers the highest risk of T1D, with an average OR of 16.(32-35). Siblings with the high-risk DR3/DR4-DQ8 genotype who shared both haplotypes with their probands have about $85 \%$ risk of T1D by the age of 15 years. (36) The larger than additive effect of the HLA DR4 and HLA DR3 haplotypes may result from the formation of HLADQ a $\beta$ trans-heterodimers from HLA-DQA $1 * 05: 01$ and HLA-DQB $1 * 03: 02$ protein chains encoded on different chromosomes. The association between HLA molecules and T1D is thought to result from genetic polymorphisms that encode for different amino acid residues in the peptide-binding pockets of HLA molecules; in turn, this impacts the binding affinity and repertoire of peptides that can be presented to T-cells. $(37,38)$ Particular amino acid residues at HLA-DQB1 position 57 and HLA-DRB1 position 13 appear important in that they impact antigen-binding properties of that particular combination. There are also protective alleles, such as DQB $1 * 06: 02$, which is in linkage disequilibrium with DRB1*15:01 (DR2) and DQA1*01:02(39) and others such as DRB1*14:01.(40) Among NHW, DQB $1 * 06: 02$ is present in about $20 \%$ of the general population but only in $1 \%$ of children with T1D.(41-43)

Besides DRB1 and DQ alleles, additional genetic factors may contribute to T1D risk. For example, DRB3, DRB4, and DRB5 alleles modify the risk conferred by DRB1 (44). Although the strength of the association is lower than with HLA DR and DQ, HLA-DPB1 and DPA1 are also associated to T1D.(45) However, Class II genes do not completely explain the association between HLA and T1D; HLA Class I genes (A, B and C) also impact T1D risk $(31,46)$ as well as age of onset, in interaction with Class II genes (DR and DQ). (47) In particular, the alleles with the strongest association with T1D were the protective $\mathrm{B} * 57: 01(\mathrm{OR}=0.19)$ and $\mathrm{B} * 39: 06$, which confers risk $(\mathrm{OR}=10.31)$. (48) HLA class I/peptide antigen complexes play a role in the development of the T-cell repertoire in the thymus and 
in antigen-specific T-cell-mediated cytotoxicity.(48) Overall, HLA-DQB1 position 57, HLA-DRB1 position 13 and HLA-DRB1 position 71 explain over 90\% of the phenotypic variance from the HLA DRB1-DQA1-DQB1 locus, HLA DPB1 contributes to about $1.5 \%$ of the variance explained, HLA-A to $1.5 \%$ and HLA-B to $1 \%$.(37)

A reduction in the frequency of high risk HLA types among individuals diagnosed with T1D has been noted over time, $(49,50)$ in particular among the youngest children.(51) This finding may suggest a shift in the relative contribution of genetics and environmental factors in the etiology of T1D. For example, elevated BMI accelerates progression to T1D (52) and the current elevated prevalence of obesity may be a factor in a growing subset of new cases of T1D.

\section{Non-HLA genes}

After the HLA region, the insulin gene (INS) has the strongest association with T1D. INS, on chromosome 11p15, tagged by $-23 \mathrm{HphI}$ (rs689) and $+1140 \mathrm{~A} / \mathrm{C}$ (rs3842753) SNPs, harbors three major insulin variable number tandem repeats (VNTR) according to the number of repeats. The highest risk is conferred by homozygosity for class I (shortest repeats). These insulin polymorphisms regulate the amount of insulin mRNA in the thymus and are likely to influence the development of immune tolerance to insulin. $(53,54)$

Besides the genes identified using candidate gene approaches, GWAS have provided a wealth of knowledge on the genetic basis of T1D, and over 50 loci have been associated with this disease(55) (reviewed in (56)), explaining about $80 \%$ of its hereditability (57). National and international research networks and studies have contributed to these investigations, which often require large sample sizes, e.g. the Type 1 Diabetes Genetic Consortium (T1DGC), (58) Diabetes and Autoimmunity Study in the Young (DAISY), (59) Diabetes Prevention Trial-1 (DPT-1),(60) TrialNet, (61, 62), BABYDIAB, (63) FinnDiane, (50) Action LADA,(64), Eurodiab,(65) The Environmental Determinants of Diabetes in the Young (TEDDY),(66) Human Biological Data Interchange type 1 diabetes repository (40), Danish study group of Diabetes in Childhood,(67) among others.

The protein tyrosine phosphatase, non-receptor type 22 (PTPN22) (rs2476601 SNP), on chromosome 1p13, which encodes lymphoid specific phosphatase (LYP), a suppressor of $\mathrm{T}$ cell activation, is also associated with T1D.(68) A gain of function LYP variant is associated with suppression of TCR signaling $(69,70)$ and reportedly promotes the survival of autoreactive T-lymphocytes in the thymus. The PTPN22 locus has also been associated with effects on the function of effector T-lymphocytes, regulatory T-lymphocytes and Blymphocytes in the periphery $(71,72)$. Other genes that modify T1D risk include the cytotoxic T-lymphocyte associated protein (CTLA-4) (rs3087243),(73) which is a negative regulator of cytotoxic $\mathrm{T}$ cells. It has been recently reported that altered post-transcriptional regulation could mediate the association between $C T L A-4$ polymorphisms and T1D.(74) In fact, Abatacept (CTLA4-Ig), which selectively binds to CD80/86, blocks the interaction with CD28 and modulates co-stimulation, and has been shown to transiently halt beta-cell loss in individuals recently diagnosed with T1D.(75) Other loci associated with T1D are the interleukin-2 receptor subunit alpha (IL2RA, CD25);(76) protein tyrosine phosphatase, nonreceptor type 2 (PTPN2);(77) interferon-induced helicase (IFIH1);(78) the basic leucine 
zipper transcription factor 2 (BACH2); (79) and ubiquitin-associated and SH3 domaincontaining protein A $(U B A S H 3 A) .(80,81) I L 2 R A$ variants causing abnormalities in sensitivity to IL2, which is critical to T-regulatory cell function, may alter the balance between T-regulatory cells and T-effector cells and thus increase risk of T1D. (82) PTPN2 may induce beta-cell apoptosis after interaction with increased local levels of interferon.(83) IFIH1 encodes melanoma differentiation-associated protein 5 (MDA5), which binds to double stranded RNA viruses and thus mediates the innate immune system's interferon response to certain viruses (reviewed in (84)). $B A C H 2$ regulates proinflammatory cytokineinduced apoptotic pathways in pancreatic beta-cells by crosstalk with PTPN2.(85) $U B A S H 3 A$ down regulates the NF-kB signaling pathway upon T-cell receptor stimulation, thus reducing $I L 2$ gene expression.(86) There is a large overlap among genes associated with autoimmune diseases that explains the frequent co-occurrence of autoimmune disease in individuals and families. For example, the frequency of variants of the PTPN22 gene is increased in T1D, rheumatoid arthritis, inflammatory bowel disease and juvenile idiopathic arthritis. (87) Of interest, Gli-similar 3 protein (GLIS3) gene region has been linked to neonatal diabetes, T1D and type 2 diabetes. (55) This protein has been implicated in the generation of beta cells, INS expression and beta-cell apoptosis.(88) Therefore, while many of the genes harbored in loci that have been associated with T1D are related to the immune function, evidence is accumulating that several genes are expressed in beta-cells and may affect beta-cell survival and function, especially in relation to inflammation, environmental stimuli and innate immune responses (reviewed in (56)). It is also possible that genes not directly involved in the immune function contribute to diabetogenesis in a subset of individuals with islet autoimmunity. Genetic variants in the transcription factor 7 like-2 (TCF7L2) locus are the strongest genetic factor in T2D.(89) Although this locus is not associated with T1D overall, individuals with T1D with milder autoimmunity, as suggested by the expression of single islet autoantibody and/or absence of high risk HLA types, are more likely to carry the T2D-associated TCF7L2 genetic variant compared to patients with T1D with stronger autoimmunity. $(90,91)$

\section{Genetic scores}

One of the current challenges is how to integrate the wealth of knowledge about T1D genetics and apply it meaningfully for diagnosis and risk assessment. For the last 15 years, investigators have proposed various models with various combinations of loci. The DAISY study follows high-risk siblings and the offspring of individuals with T1D, as well as newborns from the general population with high-risk HLA genes $(59,92)$. In this study, the addition of PTPN22 and $U B A S H 3 A$ SNPs to HLA-DR, DQ genotyping improved T1D risk prediction. In survival analysis, $45 \%$ of general population DAISY children with PTPN22 rs2476601 TT or HLA-DR3/4 and UBASH3A rs11203203 AA genotypes developed diabetes by age 15 , compared to $3 \%$ of children with all other genotypes.(93) The addition of non-HLA markers to HLA-DR3/4, DQ8 did not improve diabetes prediction in DAISY first-degree relatives.

The BABYDIAB study follows children of parents with T1D from birth. In this study, a genetic score developed with 8 non-HLA SNPs (IFIH1, CTLA4, PTPN22, IL18RAP, $S H 2 B 3, K I A A 0350, C O B L$ and $E R B B 3$ ) was predictive of T1D in children with high-risk 
HLA genotypes.(94) BABYDIAB investigators developed a second score that used odds ratios to weigh SNPs, and included HLA in addition to nine SNPs in the PTPN22, INS, IL2RA, ERBB3, ORMDL3, BACH2, IL27, GLIS3 and RNLS genes. (95) This 10-factor score has recently been tested for prediction of T1D in two DAISY cohorts, namely, firstdegree relatives, where it was demonstrated superior to combinations with fewer SNPs, and the general population, where it was not superior to the 3-factor model (96).

Most recently, the Exeter group developed a T1D Genetic Score to identify individuals who became insulin dependent among young adults with diabetes (97) and discriminate T1D from monogenic diabetes. (98) This score was developed studying participants in the Wellcome Trust Case Control Consortium ( $\mathrm{n}=3,887$ ), in which it was highly discriminative of T2D (AUC 0.88). This score was validated in the South West England Cohort, where it predicted insulin deficiency in a group of 20-40 y/o young adults with diabetes $(n=223$, excluded monogenic and secondary diabetes) (AUC 0.87). The score was developed by taking the first 30 T1D-associated SNPs, ranked and weighed by OR.(97) Using just the first 9 SNPs (i.e. DR3/DR4-DQ8, DR3/DR3, DR4-DQ8/DR4-DQ8, DR4-DQ8/X, DR3/X, HLA-24, HLA-B-57:01, HLADRB1-15, PTPN22, INS, IL2RA, ERBB3) returned similar predictive ability. The same T1D genetic risk score, in another study, could discriminate T1D from monogenic diabetes.(97-99) The T1D-GRS was also highly discriminative of monogenic diabetes (MODY or monogenic neonatal diabetes) and T1D.(98).

\section{Genetics and the stages of type 1 diabetes}

The onset of T1D symptoms is the clinical manifestation of the disease process that results from the interaction of predisposing genetic factors with environmental exposures, which eventually leads to a T-cell mediated, B-cell facilitated, autoimmune attack on beta-cells. $(100,101)$ The presence of islet cell autoantibodies is presently the earliest and more robust biomarker of islet autoimmunity.(102) Autoantibody responses to at least two islet antigens define the first stage of T1D (Stage 1); at this point remissions are rare. Stage 2 T1D is defined as the presence of two or more islet autoantibodies and dysglycemia, that is, glucose metabolism abnormalities that do yet not meet diabetes criteria. Stage 3 develops when the established glycemic thresholds for diabetes diagnosed are exceeded.(103) Although remissions after Stage 1 are rare, the risk and rate of progression vary based upon genetics, age at seroconversion, autoantibody titers and body mass index (BMI).(33, 52, 104, 105)

As data on the preclinical stages of T1D accumulates, it has become clear that the influence of genetic factors in T1D varies by disease stage. Prospective studies such as DAISY and TEDDY follow children at increased risk for diabetes since birth and therefore assess the impact of genetic factors during disease progression. In multivariate analyses adjusting for family history and HLA-DR3/4 genotype in DAISY $(93,106)$, PTPN22 (rs2476601) and two $U B A S H 3 A$ (rs11203203 and rs9976767) SNPs were associated with development of islet autoimmunity, while INS, UBASH3A and IFIH1 were significantly associated with progression from islet autoimmunity to diabetes. In TEDDY participants carrying high-risk HLA genotypes, four SNPs achieved significant association to development of islet autoimmunity using time-to-event analysis: rs2476601 in PTPN22, rs2292239 in erb-b2 receptor tyrosine kinase 3 (ERBB3), rs3184504 in SH2B3, and rs1004446 in INS.(107) The 
Finnish Pediatric Diabetes Register, using transmission analysis, found that the DR3DQ2/DR4/DQ8 genotype influenced the development of islet autoantibodies, but not subsequent progression to symptomatic (Stage 3) T1D.(35)

\section{The role of race and ethnicity}

Most of the current knowledge of T1D genetics originates from studies conducted in NHW populations, in which the highest disease prevalence is observed.(5) However, T1D is still the most frequent type of pediatric diabetes in all other racial and ethnic groups in the United States,(1) with growing importance as the United States demographics shift. As noted earlier, recent data revealed that the rise in T1D is disproportionately affecting Hispanics in the United States.(2) Furthermore, T1D occurs in many non-Caucasian populations in the world.(7) Most studies find racial/ethnic differences in the genetic, immunologic, metabolic and clinical characteristics of T1D (108-114), some of which may impact disparities in management and clinical outcomes (115). The frequency of HLA haplotypes and genotypes classically associated with T1D varies among populations. Importantly, their susceptibility or protective effects on T1D risk vary as well.(116) For example, multiple although not all (109) reports have demonstrated a reduced frequency of DR3 (117-119) but increased frequency of protective allele (DRB1*14:02) in Hispanics compared to NHWs.(119) The SEARCH Study revealed higher frequency of the susceptibility DRB1*04:01 - DQB1*03:02 haplotype in NHWs than Hispanic youth with T1D while DRB1*04:05 - DQB1*03:02 and DRB1*04:07 - DQB1*03:02 were more frequent in Hispanics than NHWs.(111) Interestingly, the DAISY study observed higher frequencies of high-risk or moderate-risk genotypes in Hispanics than NHW among 5,000 newborns from general population in the Denver area.(59) The DR3 and DR7 haplotypes found in African-Americans have only a small difference with the version most common in NHWs, and yet their effects on risk are opposite. For example, the NHW DR7 is DRB1*07:01-DQA1*02:01-DQB1*02:02 and is protective for T1D, while among AfricanAmericans DR7 is most often found as DRB1*07:01-DQA1*03:01-DQB1*02:02 and confers susceptibility. The African DR3 haplotype, DRB1*03:02-DQA1*04:01DQB1*04:02, is protective while the DRB1*03:01-DQA1*05:01-DQB1*02:01 haplotype, most often found in other races, confers risk (reviewed in (116)). As strategies for T1D diagnosis and prediction rely more heavily on genetics, it will be important to consider racial and ethnic differences in the genetics of T1D.

\section{Conclusions and future directions}

Decades of research show that genetics play a key role in the etiology and pathogenesis of T1D. An extensive body of knowledge has accumulated on the genetic factors that influence the development of the disease. However, the genetics of T1D are complex and polygenic, and modulated by imprinting (e.g. INS (120)), alternative splicing of islet autoantigen mRNAs (e.g. IA-2)(121), gene-gene interaction, and gene-environment interaction, for example, through epigenetic modifications $(87,122)$, or mediated by retrovirus $(123,124))$. Besides genetic factors that are directly involved in controlling immune response and beta cell function, there is mounting evidence that other pathogenic mechanisms may be involved. For example, as it becomes evident that elevated BMI contributes to the 
progression to T1D,(52) the genetics of obesity is emerging as additional factor. Similarly, genes that regulate pathogenic mechanisms of T2D may play a role in subsets of individuals with T1D. $(90,91)$ Additional complexity lies in racial/ethnic differences, with most of the current knowledge stemming from studies in Caucasian populations, despite the evidence that T1D occurs in all racial/ethnic group and, in the United States, is growing most rapidly among Hispanics.(2)

A critical application of genetics is to improve prediction so that strategies can be designed and implemented to prevent disease in individuals at risk (reviewed in $(104,125)$ ).

Furthermore, genetics could play a unique role as time-independent tools for the diagnosis of diabetes in the large and growing number of cases with unclear diagnosis $(126,127)$, and the prognosis of clinical outcomes in individuals with T1D. Converting our advances in T1D genetics into tools that are applicable to clinical needs is one of the great current challenges that should drive the field. (99)

\section{Acknowledgments}

This work was also partially supported by the NIH grant U01-DK-103180-01 (M.J.R.), the American Diabetes Association (ADA) Grant 1-14-CD-17 (A.K.S) and the Diabetes Research Institute Foundation, Hollywood, FL (A.P.).

\section{References}

1. Liese AD, D'Agostino RB Jr, Hamman RF, Kilgo PD, Lawrence JM, et al. Group SfDiYS. The burden of diabetes mellitus among US youth: prevalence estimates from the SEARCH for Diabetes in Youth Study. Pediatrics. 2006; 118:1510-8. [PubMed: 17015542]

2. Mayer-Davis EJ, Lawrence JM, Dabelea D, Divers J, Isom S, Dolan L, et al. Incidence Trends of Type 1 and Type 2 Diabetes among Youths, 2002-2012. The New England journal of medicine. 2017; 376:1419-29. [PubMed: 28402773]

3. Imperatore G, Boyle JP, Thompson TJ, Case D, Dabelea D, Hamman RF, et al. Projections of type 1 and type 2 diabetes burden in the U.S. population aged <20 years through 2050: dynamic modeling of incidence, mortality, and population growth. Diabetes care. 2012; 35:2515-20. [PubMed: 23173134]

4. Gale EA. The rise of childhood type 1 diabetes in the 20th century. Diabetes. 2002; 51:3353-61. [PubMed: 12453886]

5. Dabelea D, Mayer-Davis EJ, Saydah S, Imperatore G, Linder B, Divers J, et al. Prevalence of type 1 and type 2 diabetes among children and adolescents from 2001 to 2009. Jama. 2014; 311:1778-86. [PubMed: 24794371]

6. Karvonen M, Viik-Kajander M, Moltchanova E, Libman I, LaPorte R, Tuomilehto J. Incidence of childhood type 1 diabetes worldwide. Diabetes Mondiale (DiaMond) Project Group. Diabetes care. 2000; 23:1516-26. [PubMed: 11023146]

7. Craig ME, Jefferies C, Dabelea D, Balde N, Seth A, Donaghue KC, et al. ISPAD Clinical Practice Consensus Guidelines 2014. Definition, epidemiology, and classification of diabetes in children and adolescents. Pediatric diabetes. 2014; 15(20):4-17. [PubMed: 25182305]

8. Diaz-Valencia PA, Bougneres P, Valleron AJ. Global epidemiology of type 1 diabetes in young adults and adults: a systematic review. BMC public health. 2015; 15:255. [PubMed: 25849566]

9. Zhou Z, Xiang Y, Ji L, Jia W, Ning G, Huang G, et al. Frequency, immunogenetics, and clinical characteristics of latent autoimmune diabetes in China (LADA China study): a nationwide, multicenter, clinic-based cross-sectional study. Diabetes. 2013; 62:543-50. [PubMed: 23086039]

10. American Diabetes A. 2. Classification and Diagnosis of Diabetes. Diabetes care. 2017; 40:S11S24. [PubMed: 27979889] 
11. Hameed S, Ellard S, Woodhead HJ, Neville KA, Walker JL, Craig ME, et al. Persistently autoantibody negative (PAN) type 1 diabetes mellitus in children. Pediatric diabetes. 2011; 12:142-9. [PubMed: 21518407]

12. Delvecchio M, Mozzillo E, Salzano G, Iafusco D, Frontino G, Patera PI, et al. Monogenic Diabetes accounts for $63 \%$ of cases referred to 15 Italian pediatric diabetes Centers during 2007-2012. The Journal of clinical endocrinology and metabolism. 2017

13. Barrett TG. Differential diagnosis of type 1 diabetes: which genetic syndromes need to be considered? Pediatric diabetes. 2007; 8(6):15-23.

14. Lutale JJ, Thordarson H, Holm PI, Eide GE, Vetvik K. Islet cell autoantibodies in African patients with Type 1 and Type 2 diabetes in Dar es Salaam Tanzania: a cross sectional study. Journal of autoimmune diseases. 2007; 4:4. [PubMed: 17963519]

15. Mrena S, Virtanen SM, Laippala P, Kulmala P, Hannila ML, Akerblom HK, et al. Models for predicting type 1 diabetes in siblings of affected children. Diabetes care. 2006; 29:662-7. [PubMed: 16505523]

16. Dorman JS, Steenkiste AR, O'Leary LA, McCarthy BJ, Lorenzen T, Foley TP. Type 1 diabetes in offspring of parents with type 1 diabetes: the tip of an autoimmune iceberg? Pediatric diabetes. 2000; 1:17-22. [PubMed: 15016238]

17. Redondo MJ, Jeffrey J, Fain PR, Eisenbarth GS, Orban T. Concordance for islet autoimmunity among monozygotic twins. The New England journal of medicine. 2008; 359:2849-50. [PubMed: 19109586]

18. Redondo MJ, Rewers M, Yu L, Garg S, Pilcher CC, Elliott RB, et al. Genetic determination of islet cell autoimmunity in monozygotic twin, dizygotic twin, and non-twin siblings of patients with type 1 diabetes: prospective twin study. Bmj. 1999; 318:698-702. [PubMed: 10074012]

19. Redondo MJ, Yu L, Hawa M, Mackenzie T, Pyke DA, Eisenbarth GS, et al. Heterogeneity of type I diabetes: analysis of monozygotic twins in Great Britain and the United States. Diabetologia. 2001; 44:354-62. [PubMed: 11317668]

20. Yang Y, Chan L. Monogenic Diabetes: What It Teaches Us on the Common Forms of Type 1 and Type 2 Diabetes. Endocrine reviews. 2016; 37:190-222. [PubMed: 27035557]

21. Nagamine K, Peterson P, Scott HS, Kudoh J, Minoshima S, Heino M, et al. Positional cloning of the APECED gene. Nature genetics. 1997; 17:393-8. [PubMed: 9398839]

22. Finnish-German AC. An autoimmune disease, APECED, caused by mutations in a novel gene featuring two PHD-type zinc-finger domains. Nature genetics. 1997; 17:399-403. [PubMed: 9398840]

23. Ochs HD, Gambineri E, Torgerson TR. IPEX, FOXP3 and regulatory T-cells: a model for autoimmunity. Immunologic research. 2007; 38:112-21. [PubMed: 17917016]

24. Hori S, Nomura T, Sakaguchi S. Control of regulatory T cell development by the transcription factor Foxp3. Science. 2003; 299:1057-61. [PubMed: 12522256]

25. Flanagan SE, Haapaniemi E, Russell MA, Caswell R, Lango Allen H, De Franco E, et al. Activating germline mutations in STAT3 cause early-onset multi-organ autoimmune disease. Nature genetics. 2014; 46:812-4. [PubMed: 25038750]

26. Velayos T, Martinez R, Alonso M, Garcia-Etxebarria K, Aguayo A, Camarero C, et al. An Activating Mutation in STAT3 Results in Neonatal Diabetes Through Reduced Insulin Synthesis. Diabetes. 2017; 66:1022-9. [PubMed: 28073828]

27. Hirschhorn JN. Genetic epidemiology of type 1 diabetes. Pediatric diabetes. 2003; 4:87-100. [PubMed: 14655265]

28. Torres JM, Cox NJ, Philipson LH. Genome wide association studies for diabetes: perspective on results and challenges. Pediatric diabetes. 2013; 14:90-6. [PubMed: 23350725]

29. Cudworth AG, Woodrow JC. Letter: HL-A antigens and diabetes mellitus. Lancet. 1974; 2:1153.

30. Noble JA, Erlich HA. Genetics of type 1 diabetes. Cold Spring Harbor perspectives in medicine. 2012; 2:a007732. [PubMed: 22315720]

31. Erlich HA, Valdes AM, McDevitt SL, Simen BB, Blake LA, McGowan KR, et al. Next generation sequencing reveals the association of DRB3*02:02 with type 1 diabetes. Diabetes. 2013; 62:261822. [PubMed: 23462545] 
32. Redondo MJ, Babu S, Zeidler A, Orban T, Yu L, Greenbaum C, et al. Specific human leukocyte antigen DQ influence on expression of antiislet autoantibodies and progression to type 1 diabetes. The Journal of clinical endocrinology and metabolism. 2006; 91:1705-13. [PubMed: 16464953]

33. Redondo MJ, Eisenbarth GS. Genetic control of autoimmunity in Type I diabetes and associated disorders. Diabetologia. 2002; 45:605-22. [PubMed: 12107741]

34. Redondo MJ, Fain PR, Eisenbarth GS. Genetics of type 1A diabetes. Recent progress in hormone research. 2001; 56:69-89. [PubMed: 11237226]

35. Ilonen J, Kiviniemi M, Lempainen J, Simell O, Toppari J, Veijola R, et al. Genetic susceptibility to type 1 diabetes in childhood - estimation of HLA class II associated disease risk and class II effect in various phases of islet autoimmunity. Pediatric diabetes. 2016; 17(22):8-16. [PubMed: 27411431]

36. Aly TA, Ide A, Jahromi MM, Barker JM, Fernando MS, Babu SR, et al. Extreme genetic risk for type 1A diabetes. Proceedings of the National Academy of Sciences of the United States of America. 2006; 103:14074-9. [PubMed: 16966600]

37. Hu X, Deutsch AJ, Lenz TL, Onengut-Gumuscu S, Han B, Chen WM, et al. Additive and interaction effects at three amino acid positions in HLA-DQ and HLA-DR molecules drive type 1 diabetes risk. Nature genetics. 2015; 47:898-905. [PubMed: 26168013]

38. Lee KH, Wucherpfennig KW, Wiley DC. Structure of a human insulin peptide-HLA-DQ8 complex and susceptibility to type 1 diabetes. Nature immunology. 2001; 2:501-7. [PubMed: 11376336]

39. Erlich HA, Griffith RL, Bugawan TL, Ziegler R, Alper C, Eisenbarth G. Implication of specific DQB1 alleles in genetic susceptibility and resistance by identification of IDDM siblings with novel HLA-DQB1 allele and unusual DR2 and DR1 haplotypes. Diabetes. 1991; 40:478-81. [PubMed: 2010048]

40. Redondo MJ, Kawasaki E, Mulgrew CL, Noble JA, Erlich HA, Freed BM, et al. DR- and DQassociated protection from type 1A diabetes: comparison of DRB $1 * 1401$ and DQA $1 * 0102$ DQB1*0602*. The Journal of clinical endocrinology and metabolism. 2000; 85:3793-7. [PubMed: 11061540]

41. Thomson G. HLA DR antigens and susceptibility to insulin-dependent diabetes mellitus. American journal of human genetics. 1984; 36:1309-17. [PubMed: 6334991]

42. Noble JA, Valdes AM, Cook M, Klitz W, Thomson G, Erlich HA. The role of HLA class II genes in insulin-dependent diabetes mellitus: molecular analysis of 180 Caucasian, multiplex families. American journal of human genetics. 1996; 59:1134-48. [PubMed: 8900244]

43. Baisch JM, Weeks T, Giles R, Hoover M, Stastny P, Capra JD. Analysis of HLA-DQ genotypes and susceptibility in insulin-dependent diabetes mellitus. The New England journal of medicine. 1990; 322:1836-41. [PubMed: 2348836]

44. Zhao LP, Alshiekh S, Zhao M, Carlsson A, Larsson HE, Forsander G, et al. Next-Generation Sequencing Reveals That HLA-DRB3, -DRB4, and -DRB5 May Be Associated With Islet Autoantibodies and Risk for Childhood Type 1 Diabetes. Diabetes. 2016; 65:710-8. [PubMed: 26740600]

45. Noble JA, Valdes AM, Thomson G, Erlich HA. The HLA class II locus DPB1 can influence susceptibility to type 1 diabetes. Diabetes. 2000; 49:121-5. [PubMed: 10615959]

46. Noble JA, Valdes AM, Bugawan TL, Apple RJ, Thomson G, Erlich HA. The HLA class I A locus affects susceptibility to type 1 diabetes. Human immunology. 2002; 63:657-64. [PubMed: 12121673]

47. Valdes AM, Thomson G, Erlich HA, Noble JA. Association between type 1 diabetes age of onset and HLA among sibling pairs. Diabetes. 1999; 48:1658-61. [PubMed: 10426387]

48. Noble JA, Valdes AM, Varney MD, Carlson JA, Moonsamy P, Fear AL, et al. HLA class I and genetic susceptibility to type 1 diabetes: results from the Type 1 Diabetes Genetics Consortium. Diabetes. 2010; 59:2972-9. [PubMed: 20798335]

49. Vehik K, Hamman RF, Lezotte D, Norris JM, Klingensmith GJ, Rewers M, et al. Trends in highrisk HLA susceptibility genes among Colorado youth with type 1 diabetes. Diabetes care. 2008; 31:1392-6. [PubMed: 18356404] 
50. Hermann R, Knip M, Veijola R, Simell O, Laine AP, Akerblom HK, et al. Temporal changes in the frequencies of HLA genotypes in patients with Type 1 diabetes--indication of an increased environmental pressure? Diabetologia. 2003; 46:420-5. [PubMed: 12687342]

51. Steck AK, Armstrong TK, Babu SR, Eisenbarth GS. Type 1 Diabetes Genetics. Stepwise or linear decrease in penetrance of type 1 diabetes with lower-risk HLA genotypes over the past 40 years. Diabetes. 2011; 60:1045-9. [PubMed: 21307077]

52. Ferrara CT, Geyer SM, Liu YF, Evans-Molina C, Libman IM, Besser R, et al. Excess BMI in Childhood: A Modifiable Risk Factor for Type 1 Diabetes Development. Diabetes care. 2017

53. Vafiadis P, Bennett ST, Todd JA, Nadeau J, Grabs R, Goodyer CG, et al. Insulin expression in human thymus is modulated by INS VNTR alleles at the IDDM2 locus. Nature genetics. 1997; 15:289-92. [PubMed: 9054944]

54. Pugliese A, Zeller M, Fernandez A Jr, Zalcberg LJ, Bartlett RJ, Ricordi C, et al. The insulin gene is transcribed in the human thymus and transcription levels correlated with allelic variation at the INS VNTR-IDDM2 susceptibility locus for type 1 diabetes. Nature genetics. 1997; 15:293-7. [PubMed: 9054945]

55. Barrett JC, Clayton DG, Concannon P, Akolkar B, Cooper JD, Erlich HA, et al. Genome-wide association study and meta-analysis find that over 40 loci affect risk of type 1 diabetes. Nature genetics. 2009; 41:703-7. [PubMed: 19430480]

56. Floyel T, Kaur S, Pociot F. Genes affecting beta-cell function in type 1 diabetes. Current diabetes reports. 2015; 15:97. [PubMed: 26391391]

57. Groop L, Pociot F. Genetics of diabetes--are we missing the genes or the disease? Molecular and cellular endocrinology. 2014; 382:726-39. [PubMed: 23587769]

58. Rich SS, Akolkar B, Concannon P, Erlich H, Hilner JE, Julier C, et al. Overview of the Type I Diabetes Genetics Consortium. Genes and immunity. 2009; 10(1):S1-4.

59. Rewers M, Bugawan TL, Norris JM, Blair A, Beaty B, Hoffman M, et al. Newborn screening for HLA markers associated with IDDM: diabetes autoimmunity study in the young (DAISY). Diabetologia. 1996; 39:807-12. [PubMed: 8817105]

60. Diabetes Prevention Trial--Type 1 Diabetes Study G. Effects of insulin in relatives of patients with type 1 diabetes mellitus. The New England journal of medicine. 2002; 346:1685-91. [PubMed: 12037147]

61. Skyler JS, Greenbaum CJ, Lachin JM, Leschek E, Rafkin-Mervis L, Savage P, et al. Type 1 Diabetes TrialNet--an international collaborative clinical trials network. Annals of the New York Academy of Sciences. 2008; 1150:14-24. [PubMed: 19120262]

62. Mahon JL, Sosenko JM, Rafkin-Mervis L, Krause-Steinrauf H, Lachin JM, Thompson C, et al. The TrialNet Natural History Study of the Development of Type 1 Diabetes: objectives, design, and initial results. Pediatric diabetes. 2009; 10:97-104. [PubMed: 18823409]

63. Ziegler AG, Hummel M, Schenker M, Bonifacio E. Autoantibody appearance and risk for development of childhood diabetes in offspring of parents with type 1 diabetes: the 2-year analysis of the German BABYDIAB Study. Diabetes. 1999; 48:460-8. [PubMed: 10078544]

64. Leslie RD, Kolb H, Schloot NC, Buzzetti R, Mauricio D, De Leiva A, et al. Diabetes classification: grey zones, sound and smoke: Action LADA 1. Diabetes/metabolism research and reviews. 2008; 24:511-9. [PubMed: 18615859]

65. Familial risk of type I diabetes in European children. The Eurodiab Ace Study Group and The Eurodiab Ace Substudy 2 Study Group. Diabetologia. 1998; 41:1151-6. [PubMed: 9794100]

66. Hagopian WA, Erlich H, Lernmark A, Rewers M, Ziegler AG, Simell O, et al. The Environmental Determinants of Diabetes in the Young (TEDDY): genetic criteria and international diabetes risk screening of 421000 infants. Pediatric diabetes. 2011; 12:733-43. [PubMed: 21564455]

67. Rambrand T, Pociot F, Ronningen KS, Nerup J, Michelsen BK. Genetic markers for glutamic acid decarboxylase do not predict insulin-dependent diabetes mellitus in pairs of affected siblings. The Danish Study Group of Diabetes in Childhood. Human genetics. 1997; 99:177-85.

68. Onengut-Gumuscu S, Ewens KG, Spielman RS, Concannon P. A functional polymorphism $(1858 \mathrm{C} / \mathrm{T})$ in the PTPN22 gene is linked and associated with type I diabetes in multiplex families. Genes and immunity. 2004; 5:678-80. [PubMed: 15526003] 
69. Bottini N, Musumeci L, Alonso A, Rahmouni S, Nika K, Rostamkhani M, et al. A functional variant of lymphoid tyrosine phosphatase is associated with type I diabetes. NatGenet. 2004; 36:337-8.

70. Vang T, Congia M, Macis MD, Musumeci L, Orru V, Zavattari P, et al. Autoimmune-associated lymphoid tyrosine phosphatase is a gain-of-function variant. NatGenet. 2005; 37:1317-9.

71. Vang T, Miletic AV, Bottini N, Mustelin T. Protein tyrosine phosphatase PTPN22 in human autoimmunity. Autoimmunity. 2007; 40:453-61. [PubMed: 17729039]

72. Menard L, Saadoun D, Isnardi I, Ng YS, Meyers G, Massad C, et al. The PTPN22 allele encoding an R620W variant interferes with the removal of developing autoreactive B cells in humans. JClinInvest. 2011; 121:3635-44.

73. Nistico L, Buzzetti R, Pritchard LE, Van der Auwera B, Giovannini C, Bosi E, et al. The CTLA-4 gene region of chromosome $2 \mathrm{q} 33$ is linked to, and associated with, type 1 diabetes. Belgian Diabetes Registry. Human molecular genetics. 1996; 5:1075-80. [PubMed: 8817351]

74. de Jong VM, Zaldumbide A, van der Slik AR, Laban S, Koeleman BP, Roep BO. Variation in the CTLA4 3'UTR has phenotypic consequences for autoreactive $T$ cells and associates with genetic risk for type 1 diabetes. Genes and immunity. 2016; 17:75-8. [PubMed: 26656450]

75. Orban T, Bundy B, Becker DJ, DiMeglio LA, Gitelman SE, Goland R, et al. Co-stimulation modulation with abatacept in patients with recent-onset type 1 diabetes: a randomised, doubleblind, placebo-controlled trial. Lancet. 2011; 378:412-9. [PubMed: 21719096]

76. Vella A, Cooper JD, Lowe CE, Walker N, Nutland S, Widmer B, et al. Localization of a type 1 diabetes locus in the IL2RA/CD25 region by use of tag single-nucleotide polymorphisms. American journal of human genetics. 2005; 76:773-9. [PubMed: 15776395]

77. Todd JA, Walker NM, Cooper JD, Smyth DJ, Downes K, Plagnol V, et al. Robust associations of four new chromosome regions from genome-wide analyses of type 1 diabetes. Nature genetics. 2007; 39:857-64. [PubMed: 17554260]

78. Smyth DJ, Cooper JD, Bailey R, Field S, Burren O, Smink LJ, et al. A genome-wide association study of nonsynonymous SNPs identifies a type 1 diabetes locus in the interferon-induced helicase (IFIH1) region. Nature genetics. 2006; 38:617-9. [PubMed: 16699517]

79. Cooper JD, Smyth DJ, Smiles AM, Plagnol V, Walker NM, Allen JE, et al. Meta-analysis of genome-wide association study data identifies additional type 1 diabetes risk loci. Nature genetics. 2008; 40:1399-401. [PubMed: 18978792]

80. Concannon P, Onengut-Gumuscu S, Todd JA, Smyth DJ, Pociot F, Bergholdt R, et al. A human type 1 diabetes susceptibility locus maps to chromosome 21q22.3. Diabetes. 2008; 57:2858-61. [PubMed: 18647951]

81. Grant SF, Qu HQ, Bradfield JP, Marchand L, Kim CE, Glessner JT, et al. Follow-up analysis of genome-wide association data identifies novel loci for type 1 diabetes. Diabetes. 2009; 58:290-5. [PubMed: 18840781]

82. Yang JH, Cutler AJ, Ferreira RC, Reading JL, Cooper NJ, Wallace C, et al. Natural Variation in Interleukin-2 Sensitivity Influences Regulatory T-Cell Frequency and Function in Individuals With Long-standing Type 1 Diabetes. Diabetes. 2015; 64:3891-902. [PubMed: 26224887]

83. Santin I, Moore F, Colli ML, Gurzov EN, Marselli L, Marchetti P, et al. PTPN2, a candidate gene for type 1 diabetes, modulates pancreatic beta-cell apoptosis via regulation of the BH3-only protein Bim. Diabetes. 2011; 60:3279-88. [PubMed: 21984578]

84. Looney BM, Xia CQ, Concannon P, Ostrov DA, Clare-Salzler MJ. Effects of type 1 diabetesassociated IFIH1 polymorphisms on MDA5 function and expression. Current diabetes reports. 2015; 15:96. [PubMed: 26385483]

85. Marroqui L, Santin I, Dos Santos RS, Marselli L, Marchetti P, Eizirik DL. BACH2, a candidate risk gene for type 1 diabetes, regulates apoptosis in pancreatic beta-cells via JNK1 modulation and crosstalk with the candidate gene PTPN2. Diabetes. 2014; 63:2516-27. [PubMed: 24608439]

86. Ge Y, Paisie TK, Newman JRB, McIntyre LM, Concannon P. UBASH3A Mediates Risk for Type 1 Diabetes Through Inhibition of T-Cell Receptor-Induced NF-kappaB Signaling. Diabetes. 2017; 66:2033-43. [PubMed: 28607106]

87. Stankov K, Benc D, Draskovic D. Genetic and epigenetic factors in etiology of diabetes mellitus type 1. Pediatrics. 2013; 132:1112-22. [PubMed: 24190679] 
88. Nogueira TC, Paula FM, Villate O, Colli ML, Moura RF, Cunha DA, et al. GLIS3, a susceptibility gene for type 1 and type 2 diabetes, modulates pancreatic beta cell apoptosis via regulation of a splice variant of the BH3-only protein Bim. PLoS genetics. 2013; 9:e1003532. [PubMed: 23737756]

89. Grant SF, Thorleifsson G, Reynisdottir I, Benediktsson R, Manolescu A, Sainz J, et al. Variant of transcription factor 7-like 2 (TCF7L2) gene confers risk of type 2 diabetes. Nature genetics. 2006; 38:320-3. [PubMed: 16415884]

90. Redondo MJ, Grant SF, Davis A, Greenbaum C, Biobank TDE. Dissecting heterogeneity in paediatric Type 1 diabetes: association of TCF7L2 rs7903146 TT and low-risk human leukocyte antigen (HLA) genotypes. Diabetic medicine : a journal of the British Diabetic Association. 2016

91. Redondo MJ, Muniz J, Rodriguez LM, Iyer D, Vaziri-Sani F, Haymond MW, et al. Association of TCF7L2 variation with single islet autoantibody expression in children with type 1 diabetes. BMJ open diabetes research \& care. 2014; 2:e000008.

92. Norris JM, Beaty B, Klingensmith G, Yu L, Hoffman M, Chase HP, et al. Lack of association between early exposure to cow's milk protein and beta-cell autoimmunity. Diabetes Autoimmunity Study in the Young (DAISY). Jama. 1996; 276:609-14. [PubMed: 8773632]

93. Steck AK, Dong F, Wong R, Fouts A, Liu E, Romanos J, et al. Improving prediction of type 1 diabetes by testing non-HLA genetic variants in addition to HLA markers. Pediatric diabetes. 2014; 15:355-62. [PubMed: 25075402]

94. Winkler C, Krumsiek J, Lempainen J, Achenbach P, Grallert H, Giannopoulou E, et al. A strategy for combining minor genetic susceptibility genes to improve prediction of disease in type 1 diabetes. Genes and immunity. 2012; 13:549-55. [PubMed: 22932816]

95. Winkler C, Krumsiek J, Buettner F, Angermuller C, Giannopoulou EZ, Theis FJ, et al. Feature ranking of type 1 diabetes susceptibility genes improves prediction of type 1 diabetes. Diabetologia. 2014; 57:2521-9. [PubMed: 25186292]

96. Frohnert BI, Laimighofer M, Krumsiek J, Theis FJ, Winkler C, Norris JM, et al. Prediction of type 1 diabetes using a genetic risk model in the Diabetes Autoimmunity Study in the Young. Pediatric diabetes. 2017

97. Oram RA, Patel K, Hill A, Shields B, McDonald TJ, Jones A, et al. A Type 1 Diabetes Genetic Risk Score Can Aid Discrimination Between Type 1 and Type 2 Diabetes in Young Adults. Diabetes care. 2016; 39:337-44. [PubMed: 26577414]

98. Patel KA, Oram RA, Flanagan SE, De Franco E, Colclough K, Shepherd M, et al. Type 1 Diabetes Genetic Risk Score: A Novel Tool to Discriminate Monogenic and Type 1 Diabetes. Diabetes. 2016; 65:2094-9. [PubMed: 27207547]

99. Florez JC. Found in Translation: A Type 1 Diabetes Genetic Risk Score Applied to Clinical Diagnosis. Diabetes care. 2016; 39:330-2. [PubMed: 26908929]

100. Eisenbarth GS. Type I diabetes mellitus. A chronic autoimmune disease. The New England journal of medicine. 1986; 314:1360-8. [PubMed: 3517648]

101. Atkinson MA, Eisenbarth GS. Type 1 diabetes: new perspectives on disease pathogenesis and treatment. Lancet. 2001; 358:221-9. [PubMed: 11476858]

102. Vardi P, Dibella EE, Pasquarello TJ, Srikanta S. Islet cell autoantibodies: pathobiology and clinical applications. Diabetes care. 1987; 10:645-56. [PubMed: 3315517]

103. Insel RA, Dunne JL, Atkinson MA, Chiang JL, Dabelea D, Gottlieb PA, et al. Staging presymptomatic type 1 diabetes: a scientific statement of JDRF, the Endocrine Society, and the American Diabetes Association. Diabetes care. 2015; 38:1964-74. [PubMed: 26404926]

104. Wherrett DK, Chiang JL, Delamater AM, DiMeglio LA, Gitelman SE, Gottlieb PA, et al. Defining pathways for development of disease-modifying therapies in children with type 1 diabetes: a consensus report. Diabetes care. 2015; 38:1975-85. [PubMed: 26404927]

105. Skyler JS, Bakris GL, Bonifacio E, Darsow T, Eckel RH, Groop L, et al. Differentiation of Diabetes by Pathophysiology, Natural History, and Prognosis. Diabetes. 2017; 66:241-55. [PubMed: 27980006]

106. Johnson K, Wong R, Barriga KJ, Klingensmith G, Ziegler AG, Rewers MJ, et al. rs11203203 is associated with type 1 diabetes risk in population pre-screened for high-risk HLA-DR,DQ genotypes. Pediatric diabetes. 2012; 13:611-5. [PubMed: 22776074] 
107. Torn C, Hadley D, Lee HS, Hagopian W, Lernmark A, Simell O, et al. Role of Type 1 DiabetesAssociated SNPs on Risk of Autoantibody Positivity in the TEDDY Study. Diabetes. 2015; 64:1818-29. [PubMed: 25422107]

108. Morahan G. Insights into type 1 diabetes provided by genetic analyses. Current opinion in endocrinology, diabetes, and obesity. 2012; 19:263-70.

109. Kostraba JN, Cruickshanks KJ, Neville TG, Lawler-Heavner J, Chase HP, Klingensmith GJ, et al. Clinical characteristics of IDDM in Hispanics and non-Hispanic whites. Little evidence of heterogeneity by ethnicity. Diabetes care. 1992; 15:1303-9. [PubMed: 1425093]

110. Barinas-Mitchell E, Pietropaolo S, Zhang YJ, Henderson T, Trucco M, Kuller LH, et al. Islet cell autoimmunity in a triethnic adult population of the Third National Health and Nutrition Examination Survey. Diabetes. 2004; 53:1293-302. [PubMed: 15111499]

111. Black MH, Lawrence JM, Pihoker C, Dolan LM, Anderson A, Rodriguez B, et al. HLAassociated phenotypes in youth with autoimmune diabetes. Pediatric diabetes. $2013 ; 14: 121-8$. [PubMed: 22913598]

112. Gandhi K, Redondo MJ. Unique Characteristics of Hispanic Youth with New Onset Type 1 Diabetes. Diabetes. 2016; (1)

113. Gay EC, Hamman RF, Carosone-Link PJ, Lezotte DC, Cook M, Stroheker R, et al. Colorado IDDM Registry: lower incidence of IDDM in Hispanics. Comparison of disease characteristics and care patterns in biethnic population. Diabetes care. 1989; 12:701-8. [PubMed: 2612305]

114. Tosur M, Redondo MJ. Heterogeneity of Type 1 Diabetes: The Effect of Ethnicity. Current diabetes reviews. 2017

115. Willi SM, Miller KM, DiMeglio LA, Klingensmith GJ, Simmons JH, Tamborlane WV, et al. Racial-ethnic disparities in management and outcomes among children with type 1 diabetes. Pediatrics. 2015; 135:424-34. [PubMed: 25687140]

116. Noble JA. Immunogenetics of type 1 diabetes: A comprehensive review. J Autoimmun. 2015; 64:101-12. [PubMed: 26272854]

117. Cruickshanks KJ, Jobim LF, Lawler-Heavner J, Neville TG, Gay EC, Chase HP, et al. Ethnic differences in human leukocyte antigen markers of susceptibility to IDDM. Diabetes care. 1994; 17:132-7. [PubMed: 8137683]

118. Emery LM, Babu S, Bugawan TL, Norris JM, Erlich HA, Eisenbarth GS, et al. Newborn HLADR,DQ genotype screening: age- and ethnicity-specific type 1 diabetes risk estimates. Pediatric diabetes. 2005; 6:136-44. [PubMed: 16109069]

119. Erlich HA, Zeidler A, Chang J, Shaw S, Raffel LJ, Klitz W, et al. HLA class II alleles and susceptibility and resistance to insulin dependent diabetes mellitus in Mexican-American families. Nature genetics. 1993; 3:358-64. [PubMed: 7981758]

120. Pugliese A, Awdeh ZL, Alper CA, Jackson RA, Eisenbarth GS. The paternally inherited insulin gene B allele (1,428 FokI site) confers protection from insulin-dependent diabetes in families. Journal of autoimmunity. 1994; 7:687-94. [PubMed: 7840860]

121. Diez J, Park Y, Zeller M, Brown D, Garza D, Ricordi C, et al. Differential splicing of the IA-2 mRNA in pancreas and lymphoid organs as a permissive genetic mechanism for autoimmunity against the IA-2 type 1 diabetes autoantigen. Diabetes. 2001; 50:895-900. [PubMed: 11289059]

122. Bansal A, Pinney SE. DNA methylation and its role in the pathogenesis of diabetes. Pediatric diabetes. 2017; 18:167-77. [PubMed: 28401680]

123. Benoist C, Mathis D. Autoimmune diabetes. Retrovirus as trigger, precipitator or marker? Nature. 1997; 388:833-4. [PubMed: 9278041]

124. Conrad B, Weidmann E, Trucco G, Rudert WA, Behboo R, Ricordi C, et al. Evidence for superantigen involvement in insulin-dependent diabetes mellitus aetiology. Nature. 1994; 371:351-5. [PubMed: 8090207]

125. Skyler JS. Primary and secondary prevention of Type 1 diabetes. Diabetic medicine : a journal of the British Diabetic Association. 2013; 30:161-9. [PubMed: 23231526]

126. Hannon TS, Arslanian SA. The changing face of diabetes in youth: lessons learned from studies of type 2 diabetes. Annals of the New York Academy of Sciences. 2015; 1353:113-37. [PubMed: 26448515] 
127. Redondo MJ, Rodriguez LM, Escalante M, Smith EO, Balasubramanyam A, Haymond MW. Types of pediatric diabetes mellitus defined by anti-islet autoimmunity and random C-peptide at diagnosis. Pediatric diabetes. 2013; 14:333-40. [PubMed: 23458188]

\title{
Abbreviations
}

\author{
AIRE Autoimmune regulator \\ APS1 autoimmune polyglandular syndrome type 1 (APS1) \\ BACH2 Basic leucine zipper transcription factor 2 \\ BMI Body mass index \\ CTLA-4 cytotoxic T-lymphocyte associated protein \\ DAISY Diabetes and Autoimmunity in the Young \\ DPT-1 Diabetes Prevention Trial-1 \\ ERBB3 Erb-b2 receptor tyrosine kinase 3 \\ GLIS Gli-similar \\ GWAS Genome-wide linkage analysis studies \\ IFH1 Interferon-induced helicase \\ IL2RA Interleukin-2 receptor subunit alpha \\ INS Insulin (gene) \\ IPEX Immune dysregulation, polyendocrinopathy, enteropathy, X-linked (IPEX) \\ LYP Lymphoid specific phosphatase \\ NHW non-Hispanic white \\ PTPN2 Protein tyrosine phosphatase, non-receptor type 2 \\ PTPN22 Protein tyrosine phosphatase, non-receptor type 22 \\ TCF7L2 Transcription factor 7 like-2 \\ TEDDY The Environmental Determinants of Diabetes in the Young \\ T1D Type 1 diabetes \\ T1DGC Type 1 Diabetes Genetic Consortium \\ T2D Type 2 diabetes \\ UBASH3A Ubiquitin-associated and SH3 domain-containing protein A \\ VNTR insulin variable number tandem repeats
}

